\title{
Unintentional injection to the bone with a pediatric epinephrine auto-injector
}

\author{
Mariam Ibrahim ${ }^{1}$ and Harold $\mathrm{Kim}^{2 *}$
}

\begin{abstract}
Background: Skin-to-bone distance (STBD) in children prescribed a pediatric epinephrine auto-injector (EAI) for anaphylaxis is not commonly measured in practice. Recent evidence suggests that children with STBD less than the exposed needle length of available pediatric EAls (dose: $0.15 \mathrm{mg}$, needle length: $12.7 \mathrm{~mm}$ ) are at risk for unintentional injections to the bone during their use for an allergic emergency.

Case presentation: Described here is a case of a female child with multiple food allergies prescribed a pediatric EAI $\left(0.15 \mathrm{mg}\right.$ EpiPen $\left.\mathrm{Jr}^{\circledR}\right)$ who experienced an unintentional injection to her femur. The patient's STBD at the recommended injection site (vastus lateralis) was shorter than the needle length of her prescribed EAI $(12.7 \mathrm{~mm})$ at the time of the injury (age: 7, height: $122 \mathrm{~cm}$; weight: $25 \mathrm{~kg}$ ), even though her weight was within the indication for this EAl $(15-30 \mathrm{~kg})$. The patient and her family were made aware of the risk of unintentional bone injection at the time the EAI was prescribed.

Conclusions: Some children, even those at an appropriate weight per the indication of available pediatric EAls $(0.15 \mathrm{mg})$, may be at risk for unintentional injections to the bone. The effects of an unintentional bone injection with an EAl can have lasting effects on a child, including pain. Healthcare providers who prescribe pediatric EAls for any child should consider evaluating this risk, inform patients and parents of the risk, and take measures to potentially mitigate unintentional bone injections. For some children, an EAl with a shorter needle length may be a more appropriate choice of treatment for anaphylaxis.
\end{abstract}

Keywords: Anaphylaxis, Children, Skin-to-bone distance, Epinephrine auto-injector, Bone injection, Needle length

\section{Background}

EAI-related injuries in children receiving epinephrine during an allergic emergency are poorly studied, and reports to that effect are sparse. Although many of the unintentional injuries that occur with EAIs are at the expense of the person performing the injection while self-administering, administering to another person, familiarizing themselves with the device, disposing the device, or during training sessions $[1,2]$, injuries to pediatric patients do occur but are rare. In a report published in 2016, Brown et al. describe 22 EAI-related injuries in children (age range 1-11 years; weight range 7-48 kg).

\footnotetext{
*Correspondence: hlkimkw@gmail.com

${ }^{2}$ Department of Medicine, Division of Clinical Immunology \& Allergy, Western University, 525 Belmont Ave W, Ste 205, Kitchener, ON N2M 5E2, Canada

Full list of author information is available at the end of the article
}

While the majority of these injuries involved lacerations to the thigh while using the EpiPen $\mathrm{Jr}^{\circledR}$ (i.e., leg flailing during the injection), two patients experienced stuck needles after administration; one in the lateral thigh of a 5 -year old patient, and one in the tibia of an 8-year old patient [3]. This study alone prompted changes to all penstyle EAI package inserts to include verbiage on the need to restrain a child's legs during an injection.

The appropriate exposed needle length for a pediatric EAI has become an issue of recent controversy [4, 5]. In children $<15 \mathrm{~kg}$, recent evidence has shown that the current needle length of pediatric EAIs (dose: $0.15 \mathrm{mg}$; needle length: $12.7 \mathrm{~mm}$; indication: $15-30 \mathrm{~kg}$ ) may put children at risk for unintentional bone injections [6, 7]. These evaluations are based on skin-to-bone distance (STBD) measurements by sonography at the recommended injection site (vastus lateralis) in children $<15 \mathrm{~kg}$. One study demonstrated that $29 \%$ of children $<15 \mathrm{~kg}(\mathrm{~N}=100)$ had 
an STBD $<12.7 \mathrm{~mm}$, which would put them at risk for an unintentional bone injection [7]. In a subgroup of children $<10 \mathrm{~kg}$ in this study, $60 \%(\mathrm{n}=25)$ would be at risk for unintentional injection to the bone based on their STBD. A more recent study showed that $43.1 \%$ of patients ( $\geq 7.5-15 \mathrm{~kg} ; \mathrm{N}=51)$ would be at risk of an unintentional bone injection if using one of the available pediatric EAIs [6]. This study determined that the appropriate needle length for children weighing $\geq 7.5-15 \mathrm{~kg}$ would be 7-8 mm. In November 2017, the U.S. Food and Drug Administration approved an EAI with a needle length of $7.27 \mathrm{~mm}$ for use in children $\geq 7.5-15 \mathrm{~kg}[8,9]$. However, it is likely that some children between 15 and $30 \mathrm{~kg}$ may have an STBD less than the needle length of available pediatric EAIs $(12.7 \mathrm{~mm})$ indicated for this weight range. A case of unintentional injection to the bone involving a female patient with an STBD less than the needle length of her pediatric EAI at the time of use is presented.

\section{Case presentation}

MS is a 10-year-old female patient diagnosed with multiple food allergies and anaphylaxis (Table 1). MS has a family history of atopy (both parents). MS's index allergic event was at 9 months of age when she presented with urticaria after contacting milk and cheese. By the age of 5, MS had been diagnosed with milk, peanut, and tree nut allergies based on clinical history, skin prick testing, serum-specific IgE testing, and oral food challenge (OFC). Also, she has dust mite and pet allergies.

Since early in life, she was prescribed a pediatric EAI (EpiPen $\mathrm{Jr}^{\circledR} ; 0.15 \mathrm{mg}$ ) in case of an allergic emergency. The first use of her prescribed EAI for MS was at age 6 , and she has had 2 subsequent allergic emergencies requiring the use of her EAI as of the date of this report (Table 2). At 6 years old, her height was $117 \mathrm{~cm}$, weight was $17.7 \mathrm{~kg}$, BMI was 12.9, and her STBD was $10.7 \mathrm{~mm}$ by ultrasound of the right mid-anterolateral thigh. At 7 years old, around her second event requiring the EpiPen $\mathrm{Jr}^{\circledR}$, her height was $122 \mathrm{~cm}$, weight was $25 \mathrm{~kg}$, and her STBD was not recorded. After this event, and during her observation period in the hospital, MS complained of pain immediately in her right thigh at the injection site. $\mathrm{X}$-ray and ultrasound results were negative. It is believed that MS suffered an unintentional bone injection with her EAI based on clinical presentation following the allergic emergency. At 9 years old, her height was $141 \mathrm{~cm}$, weight was $30 \mathrm{~kg}$, and her STBD was $12.1 \mathrm{~mm}$. In 2017, MS was evaluated again for pain and discomfort in her right thigh.

The indication for the EpiPen $\mathrm{Jr}^{\circledR}$ is for children between 15 and $30 \mathrm{~kg}$ and this device has a needle length of $12.7 \mathrm{~mm}$. MS and her parents were made aware that use of her prescribed EAI could cause an unintentional injection to the bone using the standard injection technique with compression. It was suggested that, prior to injection, the vastus lateralis muscle be squeezed as to avoid full compression while using her EAI because of the high risk of unintentional bone injection.

This case of possible bone injection was reported to Health Canada.

\section{Conclusions}

Needle length of currently available EAIs remains an open area of inquiry and investigation [4, 5]. Unfortunately, there is little evidence to support age-, weight-, thigh circumference-, or BMI-specific needle length recommendations since the suitability of these biomarkers for this purpose has not been thoroughly investigated in large studies. This remains an area of unmet need. Previous work has shown that the risk of overpenetration with needles that are $25 \mathrm{~mm}$ and $31.75 \mathrm{~mm}$ in length in children $\geq 1$ year for routine vaccinations is 11 and $39 \%$, respectively [10]. Currently, the CDC recommends vaccination to the vastus lateralis at a 90-degree angle with a $15.8 \mathrm{~mm}$ needle for infants up to 12 months and a $25.4 \mathrm{~mm}$ needle for children 1 month and older, and either a $15.8 \mathrm{~mm}$ (deltoid) or $25.4 \mathrm{~mm}$ needle (thigh) for children 1-2 years old [11]. With manual delivery by needle and syringe, the angle of entry can be altered to correct for short STBD if suspected. However, pediatric EAIs have been engineered to be used with compression, as instructed by their prescribing information. Even with an exposed needle length of $12.7 \mathrm{~mm}$, the needle may be

Table 1 Notable case findings related to food allergy testing

\begin{tabular}{|c|c|c|c|}
\hline Age, years & $\leq 5$ & 6 & 9 \\
\hline Food allergy testing & $\begin{array}{l}\text { SPTs positive to baked milk ( } 6 \mathrm{~mm} \text { ) } \\
\text { SPTs positive to real pistachio and to extracts } \\
\text { of cashew ( } 6 \mathrm{~mm}) \\
\text { SPTs positive to dust mites, molds, cat, dog } \\
\text { SPTs to peanut and almond were borderline } \\
\text { SPTs to soy, shrimp, and wheat were negative } \\
\text { OFC to peanut positive. Rash appeared on } \\
\text { face swollen conjunctiva after } 8 \text { peanuts } \\
\text { but then resolved }\end{array}$ & $\begin{array}{l}\text { Serum-specific lgE to milk was } \\
\text { positive at } 27.40 \\
\text { Serum-specific lgE to cashew was } \\
\text { positive at } 10.80 \\
\text { This would suggest a risk of about } \\
\text { 95-100\% for anaphylaxis with } \\
\text { a significant ingestion of either } \\
\text { allergen }\end{array}$ & $\begin{array}{l}\text { Serum-specific lgE to milk was } 17.30 \\
\text { Serum-specific lgE to cashew was positive } \\
\text { at } 14.40 \\
\text { Serum specific lgE to pistachio was positive } \\
\text { at } 18.10 \\
\text { This would suggest a risk of about } \\
95-100 \% \text { for anaphylaxis with a signifi- } \\
\text { cant ingestion of these allergens }\end{array}$ \\
\hline
\end{tabular}


Table 2 Notable case history related to pediatric EAI use

\begin{tabular}{|c|c|c|c|}
\hline Age at event, years & 6 years $(2013)$ & 7 years $(2014)$ & 9 years (2017) \\
\hline Height (cm) & 117 & 122 & 141 \\
\hline Weight (kg) & 17.7 & 25 & 30 \\
\hline STBD (with compression, mm) & 10.7 & 11.1 & 12.1 \\
\hline Suspected/known allergen & Milk & Cake with cashew & $\begin{array}{l}\text { "Snack Pack" bakery } \\
\text { shop dessert } \\
\text { (tapioca, car- } \\
\text { rageenan) }\end{array}$ \\
\hline Symptoms/acute care & $\begin{array}{l}\text { MS ingested milk and her caregiver adminis- } \\
\text { tered the EpiPen } \mathrm{Jr}^{\circledR} \text { because she thought MS } \\
\text { complained of throat itchiness }\end{array}$ & $\begin{array}{l}\text { MS had immediate shortness of breath, hives, } \\
\text { throat tightness, and lip swelling } \\
\text { Her mother gave her the EpiPen Jr }{ }^{\circledR} \text { in the right } \\
\text { mid-anterolateral thigh } \\
\text { Epinephrine worked immediately, and she } \\
\text { improved within } 30 \mathrm{~s} \\
\text { MS had transient shakes, tachycardia, fatigue } \\
\text { lasting approximately } 3 \text { min } \\
\text { MS was taken to and observed in the Emer- } \\
\text { gency Department. MS complained of pain } \\
\text { immediately in her right thigh at the injec- } \\
\text { tion site, which has persisted over time } \\
\text { X-ray and ultrasound were negative }\end{array}$ & $\begin{array}{l}\text { MS had an immedi- } \\
\text { ate throat swell- } \\
\text { ing and shortness } \\
\text { of breath } \\
\text { MS was given } 2 \\
\text { doses of epineph- } \\
\text { rine } \\
\text { Her symptoms } \\
\text { improved within } \\
\text { minutes }\end{array}$ \\
\hline Follow up case notes & \multicolumn{3}{|c|}{$\begin{array}{l}\text { In August 2017, MS was examined for bony lesions, fracture, or soft tissue disorders that could explain her continued } \\
\text { discomfort and pain } \\
\text { The previous allergic emergency in } 2014 \text { requiring the use of her EAl was noted } \\
\text { Negative X-ray and ultrasound of right femur and no evidence of muscular injury or hematoma. No discrete solid or } \\
\text { cystic lesions } \\
\text { It was noted that she was skeletally immature }\end{array}$} \\
\hline Long-term management & \multicolumn{3}{|c|}{$\begin{array}{l}\text { Keep prescribed EpiPen } \mathrm{Jr}^{\circledR} \text { available } \\
\text { Instructions on how to give the EpiPen } \mathrm{Jr}^{\circledR} \text { without full muscle compression } \\
\text { Continue strict avoidance of milk, raw peanut, cashew, hazelnut, pecan, and pistachio }\end{array}$} \\
\hline
\end{tabular}

too long for many children as more recent evidence has shown $[6,7]$.

In this case report, the subject's parents and allergist believe that the EAI delivered at age 7 years hit and possibly penetrated the bone. Although, we could not confirm this with radiographic evidence, there was strong clinical evidence to support bone injection. First, bone pain and tenderness at the injection site was present immediately after the injection lasting for at least 2 years. Also, she had possible epinephrine side effects after the EAI injection at age 7 . She had shakes, tachycardia and fatigue immediately after her allergic reaction and epinephrine delivery. The symptoms could have been due to the anaphylaxis or due to side effects of intramuscular delivery of epinephrine. We believe that the epinephrine may have been delivered through the cortical bone into the intraosseous space, which could lead to immediate intravenous delivery of the drug. At the time of the unintentional bone injection (patient height: $122 \mathrm{~cm}$; patient weight: $25 \mathrm{~kg}$ ), the patient's STBD with compression was less than the needle length $(12.7 \mathrm{~mm})$ of her prescribed pediatric EAI (EpiPen $\mathrm{Jr}^{\circledR} 0.15 \mathrm{mg}$ ). In this case, we had previously measured STBD and knew that there was a risk for unintentional bone injection in this patient.
In conclusion, our case illustrates that a risk for unintentional bone injection of epinephrine with currently available EAIs exists for children between 15 and $30 \mathrm{~kg}$. However, most healthcare providers do not perform ultrasound studies on children to determine STBD. Therefore, they are unlikely to be aware of the risk for unintentional bone injections with currently available pediatric EAIs; i.e. devices indicated for children $15-30 \mathrm{~kg}$. Unintentional injection of epinephrine to the bone in this case may have caused immediate systemic side effects as well as symptoms of pain and discomfort that persisted in the patient well after the initial adverse event. EAIs should be designed taking this risk into consideration.

\section{Authors' contributions}

HK curated, analysed, and interpreted the data reported here regarding the patient's food allergy and anaphylaxis history, as well as the injury caused by the patient's prescribed EAl, final approval. MI critically reviewed and revised the manuscript. All authors read and approved the final manuscript.

\section{Author details}

${ }^{1}$ Department of Engineering, University of Guelph, Guelph, ON, Canada.

${ }^{2}$ Department of Medicine, Division of Clinical Immunology \& Allergy, Western

University, 525 Belmont Ave W, Ste 205, Kitchener, ON N2M 5E2, Canada. 


\section{Authors' information}

Dr. Harold Kim, MD, FRCP(C) is a practicing Allergist and Clinical Immunologist. He holds appointments at McMaster University as an Assistant Clinical Professor and Western University as an Adjunct Professor. Dr. Kim is the Vice President for the Canadian Society of Allergy and Clinical Immunology (CSACI). He is also a Past President of the Canadian Network for Respiratory Care (CNRC). He is the Chief/Chair of the Division of Clinical Immunology and Allergy at the Western University. Mariam Ibrahim is a student in the Department of Biomedical Engineering at the University of Guelph.

\section{Acknowledgements}

The authors thank Sean M. Gregory, Ph.D., Hybrid Healthcare Communications, for medical writing assistance and formatting of the manuscript, which was conducted in accordance with GPP-3 guidelines.

\section{Competing interests}

Over the last 12 months, HK reports receiving consulting fees or serving as a speaker for Astrazeneca, Aralez, CSL Behring, kaléo, Novartis, Pediapharm, Sanofi, and Shire. Ml has no competing interests to report.

\section{Availability of data and materials statement}

All data was curated and summarized from the patient's electronic medical records. In accordance with the patient's right to privacy, unnamed data from her medical records were used for this report. Data sharing is not applicable to this article as no datasets were generated or analysed during the current study.

\section{Consent for publication}

Consent to use unnamed data for this case study report was provided by the patient and her parents.

\section{Ethics approval and consent to participate}

Not a clinical trial. Not applicable.

\section{Funding}

Medical writing and editorial assistance was funded by kaléo.

\section{Publisher's Note}

Springer Nature remains neutral with regard to jurisdictional claims in published maps and institutional affiliations.
Received: 14 February 2018 Accepted: 18 April 2018

Published online: 20 August 2018

\section{References}

1. Simons FE, Edwards ES, Read EJ Jr, Clark S, Liebelt EL. Voluntarily reported unintentional injections from epinephrine auto-injectors. J Allergy Clin Immunol. 2010;125:419-23.

2. Simons FE, Lieberman PL, Read EJ Jr, Edwards ES. Hazards of unintentional injection of epinephrine from autoinjectors: a systematic review. Ann Allergy Asthma Immunol. 2009;102:282-7.

3. Brown JC, Tuuri RE, Akhter $\mathrm{S}$, et al. Lacerations and embedded needles caused by epinephrine autoinjector use in children. Ann Emerg Med. 2016;67:307-15.

4. Song TT, Lieberman P. Epinephrine auto-injector needle length: what is the ideal length? Curr Opin Allergy Clin Immunol. 2016;16:361-5.

5. Dreborg S, Wen X, Kim L, et al. Do epinephrine auto-injectors have an unsuitable needle length in children and adolescents at risk for anaphylaxis from food allergy? Allergy Asthma Clin Immunol. 2016;12:11.

6. Kim H, Dinakar C, McInnis P, et al. Inadequacy of current pediatric epinephrine autoinjector needle length for use in infants and toddlers. Ann Allergy Asthma Immunol. 2017;118:719-25.

7. Kim L, Nevis IF, Tsai G, et al. Children under $15 \mathrm{~kg}$ with food allergy may be at risk of having epinephrine auto-injectors administered into bone. Allergy Asthma Clin Immunol. 2014;10:40.

8. Auvi-Q prescribing information. Kaléo pharmaceuticals, Richmond, VA; 2017.

9. Kaléo pharmaceuticals. NDA 201-739, S-008 and S-009. Auvi-Q (epinephrine injection, USP) auto-injector. Submitted May 19, 2017. Reviewed September 26, 2017.

10. Lippert WC, Wall EJ. Optimal intramuscular needle-penetration depth. Pediatrics. 2008:122:e556-63.

11. Centers for Disease Control. Chapter 6: vaccine administration. In: Epidemiology and prevention of vaccine-preventable diseases. Page last updated on 8 Sept 2015. https://www.cdc.gov/vaccines/pubs/pinkbook/ vac-admin.html\#route. Accessed 7 Dec 2017.
Ready to submit your research? Choose BMC and benefit from:

- fast, convenient online submission

- thorough peer review by experienced researchers in your field

- rapid publication on acceptance

- support for research data, including large and complex data types

- gold Open Access which fosters wider collaboration and increased citations

- maximum visibility for your research: over 100M website views per year

At BMC, research is always in progress.

Learn more biomedcentral.com/submissions 